University of Nebraska - Lincoln

DigitalCommons@University of Nebraska - Lincoln

$5-24-1999$

\title{
Genetic variation in geographical populations of western and Mexican corn rootworm
}

\author{
A. L. Szalanski \\ University of Nebraska-Lincoln, aszalan@uark.edu \\ R. L. Roehrdanz \\ USDA-ARS, Biosciences Research Laboratory, Fargo, ND, Richard.Roehrdanz@ars.usda.gov \\ D. B. Taylor \\ USDA-ARS, Midwest Livestock Insects Research Laboratory, Lincoln, NE, dave.taylor@ars.usda.gov \\ L. Chandler \\ USDA-ARS, Northern Grain Insects Research Laboratory, Brookings, SD, larry.chandler@ars.usda.gov
}

Follow this and additional works at: https://digitalcommons.unl.edu/plantpathpapers

Part of the Plant Pathology Commons

Szalanski, A. L.; Roehrdanz, R. L.; Taylor, D. B.; and Chandler, L., "Genetic variation in geographical populations of western and Mexican corn rootworm" (1999). Papers in Plant Pathology. 105.

https://digitalcommons.unl.edu/plantpathpapers/105

This Article is brought to you for free and open access by the Plant Pathology Department at DigitalCommons@University of Nebraska - Lincoln. It has been accepted for inclusion in Papers in Plant Pathology by an authorized administrator of DigitalCommons@University of Nebraska - Lincoln. 


\section{Genetic variation in geographical populations of western and Mexican corn rootworm}

\author{
A. L. Szalanski, ${ }^{1}$ R. L. Roehrdanz, ${ }^{2}$ D. B. Taylor ${ }^{3}$ and \\ L. Chandler ${ }^{4}$ \\ ${ }^{1}$ Department of Plant Pathology, University of Nebraska- \\ Lincoln, Lincoln, NE, U.S.A., ${ }^{2}$ USDA-ARS, Biosciences \\ Research Laboratory, Fargo, ND, U.S.A., ${ }^{3}$ USDA-ARS, \\ Midwest Livestock Insects Research Laboratory, Lincoln, \\ NE, U.S.A., and ${ }^{4}$ USDA-ARS, Northern Grain Insects \\ Research Laboratory, Brookings, SD, U.S.A.
}

\begin{abstract}
Genetic variation in the nuclear rDNA ITS1 region of western corn rootworm, Diabrotica virgifera virgifera (WCR), and Mexican corn rootworm, D. v. zeae (MCR) was studied. Two sites were detected which differentiated WCR and MCR in the 642-base sequence. Polymerase chain reaction-restriction fragment length polymorphism (PCR-RFLP) analysis of the first internal transcribed spacer region (ITS1) sequence revealed no variation within or among the twelve WCR and two MCR populations. PCR-RFLP of $75 \%$ of the mitochondrial DNA genome detected one significant polymorphic site out of the approximately 190 restriction sizes observed in WCR. The polymorphism did not differentiate geographical populations of WCR and is not diagnostic for the subspecies. The low levels of variation observed in WCR suggests either high levels of gene flow or a recent geographical expansion from a relatively small base. Gene flow would facilitate the rapid spread of traits that could compromise control programmes, such as insecticide resistance or behavioural modifications. The minimal genetic differentiation between WCR and MCR raises questions about the evolutionary history of these subspecies and how the distinct phenotypes are maintained.
\end{abstract}

Received 22 December 1998; accepted 24 May 1999. Correspondence: Allen L. Szalanski, Department of Plant Pathology, University of NebraskaLincoln, 406 Plant Science, Lincoln, NE 68583-0722, U.S.A. Tel.: (402) 472-3167. Fax: (402) 472 2853. E-mail: aszalans@unlinfo.unl.edu
Keywords: ITS1, mtDNA, PCR-RFLP, Diabrotica, population variability, Wolbachia.

Introduction

Western corn rootworm, Diabrotica virgifera virgifera LeConte (WCR), and Mexican corn rootworm, D. v. zeae Krysan \& Smith (MCR) along with several other species of diabroticite beetles are among the most economically and environmentally important insect pests of maize production systems in the USA (Levine \& Oloumi-Sadeghi, 1991). Diabroticite beetles are members of Chrysomelidae, many of which attack agricultural crops. Other major pests in the group include Northern corn rootworm, Diabrotica barberi Smith and Lawrence (NCR), western spotted cucumber beetle, $D$. undecimpunctata undecimpunctata Mannerheim (WSCB) and southern corn rootworm, D. u. howardi Barber (SCR). In the USA, 20-25 million acres of corn are treated annually with soil insecticides to protect the crop from corn rootworm larval feeding damage (Fuller et al., 1997). Soil insecticides applied for corn rootworm represent one of the major uses of insecticide in the USA. In some locations, insecticides are used against adult beetles as well. This is costly both economically and environmentally. The economic impact of WCR has prompted interest in an area-wide management approach using integrated pest management (IPM) procedures to control rootworm damage.

WCR is distributed from north-western Mexico through the central plains of the USA and east to New Jersey, excluding the south-eastern USA. In the south-western USA, WCR is replaced by MCR which ranges from central America through eastern Mexico to Texas and Oklahoma (Krysan, 1986; Krysan \& Smith, 1987). MCR has been observed infesting sorghum as well as corn (Stewart et al., 1995). WCR has spread rapidly eastward across the USA from the Western Great Plains to the east coast since 1940. Some populations of WCR have developed insecticide resistance in a relatively short period of time (Ball \& Weekman, 1963; Metcalf, 1983; Meinke et al., 1998). Other populations have shown a propensity to disrupt 
crop rotation programmes by depositing eggs outside of corn fields, particularly in soybeans (Levine \& OloumiSadeghi, 1991). Morphological features can distinguish adult MCR and WCR except in a narrow zone of overlap where a few intermediate phenotypes have been observed. However, larvae cannot be differentiated (Krysan et al., 1980; Krysan, 1986). Identification of Diabrotica larvae to species is difficult and for several species is impossible (Krysan, 1986). Despite the benefits that genetic analyses of WCR and MCR may provide towards diagnostics, dispersal, insecticide resistance and the implementation of area-wide control programmes, little research has been conducted on these two important subspecies.

The purpose of this study was to examine genetic variation in local and dispersed populations of WCR and MCR. Portions of the nuclear and mitochondrial genomes were examined. The first internal transcribed spacer region (ITS1), located between the $18 \mathrm{~S}$ and $5.8 \mathrm{~S}$ nuclear ribosomal DNA (rDNA) genes, was amplified using polymerase chain reaction (PCR) and subjected to DNA sequencing and restriction fragment length polymorphism (RFLP) analyses. PCR and long PCR was used to amplify two amplicons, representing about $75 \%$ of the mitochondrial DNA (mtDNA) for RFLP analysis.

\section{Results}

The ITS1 primer pair produced amplicons of $642 \mathrm{bp}$ for both WCR and MCR. Three WCR (Brookings, SD; Dey, NE; Mead, NE) (GenBank accession numbers AF155569 to AF155571), and two MCR (Temple, TX; Uvalde, TX) (GenBank AF155572, AF155573), were sequenced (Table 1). No sequence variation was detected in the amplified portions of the $18 \mathrm{~S}$ and $5.8 \mathrm{~S}$ ribosomal RNA (RNA) coding regions among WCR and MCR. No intrasubspecific variation was observed within either WCR or MCR, but two ITS1 sites differentiated the subspecies. Nucleotide 367 of MCR is ' $G$ ' whereas WCR has a 'T' at this position. At nucleotide 598 , a poly A run is $9 \mathrm{bp}$ in MCR, but only 8 in WCR (Fig. 1). Sequence divergence between WCR and MCR is about $0.3 \%$ in the ITS1 region. The ITS1 region of SCR was also amplified and sequenced (GenBank U90334) and NCR (GenBank AF155574) for comparison (Fig. 1). The SCR sequence was 752 bp, approximately 110 bp larger than WCR, MCR and NCR. A 102-bp insert between the $3^{\prime}$ end of the $18 \mathrm{~S}$ gene and ITS1 and a 14bp insertion within ITS1 accounted for the size difference. Nucleotide sequence divergence between $D$. virgifera and SCR was about $13 \%$ when the two large insertions are considered as single traits.

PCR-RFLP analysis of the ITS1 amplicon using the restriction enzymes Apol, Ddel, Dral, Rsal and Taql detected fourteen restriction sites (Table 2). Ten of the fourteen restriction sites were in the 417-bp ITS1 region

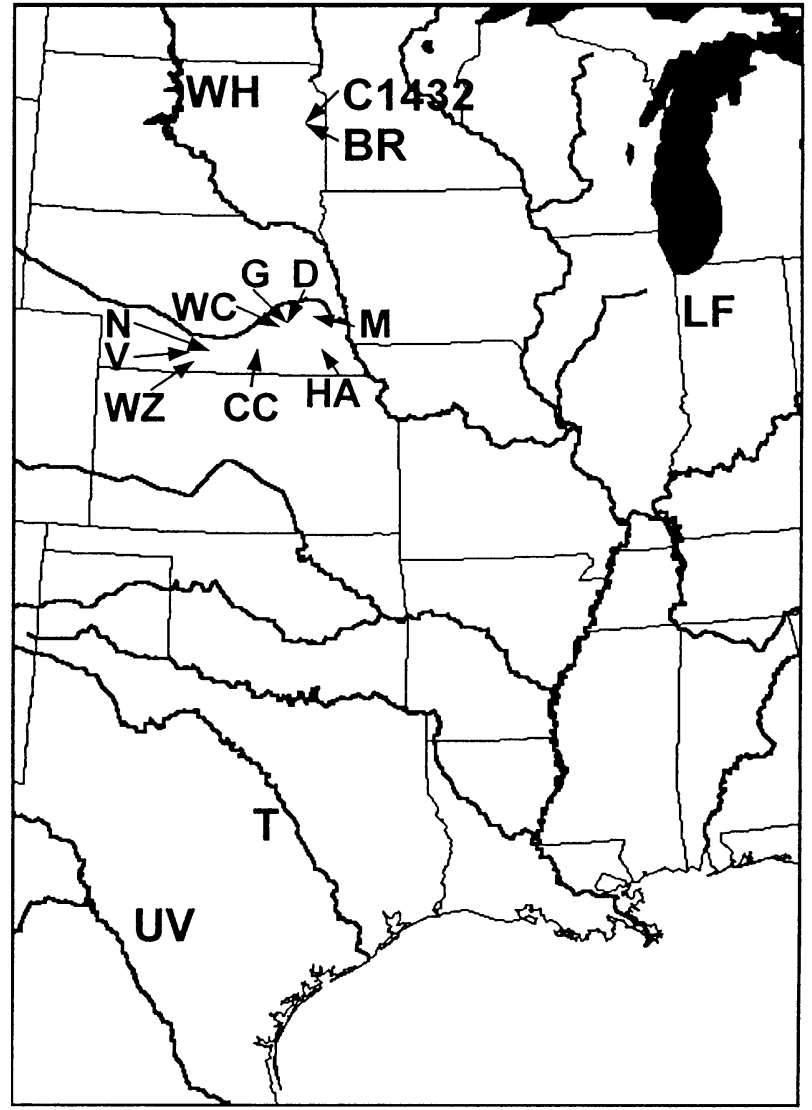

Figure 1. Western and Mexican corn rootworm collection sites. Abbreviations correspond to Table 1.

and screened approximately $12 \%$ of the region. Analysis of four to five individuals per population revealed no variation within or among twelve WCR populations (LF excluded) and two MCR populations. None of the restriction enzymes in the Webcutter database (Heiman, 1997) differentially cleaved either of the polymorphic sites observed in the nucleotide sequences.

The mtDNA long PCR amplicons 12S-N4 $(5.7 \mathrm{~kb})$ and $\mathrm{CB} 2 \mathrm{H}-\mathrm{C} 1(8.7 \mathrm{~kb})$ partially overlap and together represented about $12 \mathrm{~kb}$ of the mitochondrial genome. Alul, Asel, Dpnll, Dral, Hinfl, Sspl, Swal and Xbal were used for the RFLP analysis. Seventy-one individuals from twelve of the thirteen WCR collections (HA excluded) and forty-six MCR from the two locations were analysed. Cleaving the PCR amplicons C1-C2 (1.6 kb) and 12S$16 \mathrm{~S}(1.2 \mathrm{~kb})$ with some of the aforementioned restriction enzymes and Msel revealed at least twenty additional restriction sites (data not shown). The approximately 190 restriction fragments detected corresponded to about 170 restriction sites (Table 2). The number of mtDNA base pairs tested by the battery of restriction enzymes exceeds 900 . Only one major polymorphism was observed in WCR, a 510-bp fragment in the Dpnll digests of the 12S-N4 fragment (Fig. 2). The band was present (pattern 
Table 1. Sampling locations and dates for collections of Diabrotica spp.

\begin{tabular}{|c|c|c|c|c|}
\hline Population & Species & $\begin{array}{l}\text { Sampling Location } \\
\text { (city, county, state) }\end{array}$ & $\begin{array}{l}\text { Resistance } \\
\text { Status }^{\mathrm{a}}\end{array}$ & Date \\
\hline $\mathrm{CC}$ & WCR & Clay Center, Clay Co., NE & $S$ & 1996 \\
\hline $\mathrm{HA}$ & WCR & Havelock, Lancaster Co., NE & $S$ & 1994 \\
\hline $\mathrm{N}$ & WCR & Nichie, Phelps Co., NE & $\mathrm{R}$ & 1996 \\
\hline WZ & WCR & Winz, Phelps Co., NE & $\mathrm{R}$ & 1996 \\
\hline V & WCR & Vandell, Phelps Co., NE & $\mathrm{R}$ & 1996 \\
\hline M & WCR & Mead, Saunders Co., NE & $S$ & 1996 \\
\hline $\mathrm{G}$ & WCR & Gresham, York Co., NE & $\mathrm{R}$ & 1996 \\
\hline WC & WCR & Waco, York Co., NE & $S$ & 1996 \\
\hline D & WCR & Dey, York Co., NE & $\mathrm{R}$ & 1996 \\
\hline C1432 & WCR & Brookings, Brookings Co., SD & $S$ & 1996 \\
\hline BR & WCR & Brookings non-diapause colony & $S$ & 1996 \\
\hline WH & WCR & Whitlock Bay, Potter Co., SD & $\mathrm{s}$ & 1996 \\
\hline LF & WCR & West Lafayette, Tippecanoe Co., IN $^{b}$ & $\mathrm{~s}$ & 1997 \\
\hline $\mathrm{T}$ & MCR & Temple, Bell Co., TX & S & 1996 \\
\hline UV & MCR & Uvalde, Uvalde Co., TX & $\mathrm{s}$ & 1997 \\
\hline
\end{tabular}

${ }^{a}$ Meinke et al., 1998. Resistant (R) or Sensitive (S) to methyl parathion and carbaryl.

${ }^{\mathrm{b}}$ Insects were obtained from a colony maintained by French Agricultural Research, Lamberton, MN. The original collection site and date collected are unknown.

Table 2. Western (WCR) and Mexican corn rootworm (MCR) restriction fragment patterns from ITS1 and mitochondrial DNA amplicons.

\begin{tabular}{|c|c|c|c|c|}
\hline Amplicon & Enzyme & & Subspecies ${ }^{a}$ & Estimated fragment size (bp) \\
\hline \multirow[t]{5}{*}{ ITS1 } & Apol & & WCR/MCR & $421,158,63$ \\
\hline & Ddel & & WCR/MCR & $306,261,75$ \\
\hline & Dral & & WCR/MCR & $479,99,36,28$ \\
\hline & Rsal & & WCR/MCR & $227,198,108,86,23$ \\
\hline & Taql & & WCR/MCR & $277,132,101,75,57$ \\
\hline \multicolumn{5}{|l|}{ mtDNA } \\
\hline \multirow[t]{13}{*}{$12 \mathrm{~S}-\mathrm{N} 4$} & Hinfl & & WCR/MCR & $1550,1500,670,600,450,440,170,130$ \\
\hline & Swal & & WCR/MCR & $\sim 3200,800,750,350,310(170)$ \\
\hline & Haelll & & WCR/MCR & $1900,1500,1300,750$ \\
\hline & Alul & 'A' & WCR (67) & $1500,1050,490,485,395,370,310,297,280,240,195,175,75^{\star}, 60^{\star}$ \\
\hline & & & MCR (46) & " \\
\hline & & 'B' & WCR (3) & $1500,1050,490,485,395,370,310,297,280,240,195,180,175$ \\
\hline & & 'C' & WCR (1) & $1500,1050,490,485,395,370,310,297,240,195$ \\
\hline & Dpnll & 'A' & WCR (47) & $1350,1250,590,470,310,240,220,170$ \\
\hline & & & MCR (46) & “ \\
\hline & & 'B' & WCR (24) & $1350,1250,590,510,470,310,240,220,170$ \\
\hline & Sspl & & WCR/MCR & $850,750,600,315,240,225,200,195,180,177,140,135,110,100,95,90,85,80,75$ \\
\hline & Asel & & WCR/MCR & $900,850,390,355,335,230,195,190,180,170,160,120-90$ ( 6 band pattern), 70,65 \\
\hline & Dral & & WCR/MCR & $1100,950,360,310,265,240,235,180,170,140,90,80,75,+7^{*}$ bands $<60$ \\
\hline \multirow[t]{9}{*}{$\mathrm{CB} 2 \mathrm{H}-\mathrm{C} 1$} & Hinfl & & WCR/MCR & $3600,1750,1400,1350$ \\
\hline & Swal & & WCR/MCR & $3100,1600,1500,810,750,510,355$ \\
\hline & Alul & & WCR/MCR & $\begin{array}{l}1500,720,700,495,490,410,405,395,360,345,315,295,275,250,235,195,170,150, \\
135,110,90,75,65\end{array}$ \\
\hline & Dpnll & & WCR/MCR & $3200,1350,1250,710,380,285,260,220,130$ \\
\hline & Sspl & 'A' & $\begin{array}{l}\text { WCR }(69) \\
\operatorname{MCR}(46)\end{array}$ & $1000,700,680,350,345,280,260,220,205,195,185,175,160,140,130,120,105,100$ \\
\hline & & 'B' & WCR (1) & $1000,700,680,410,350,280,260,220,205,195,185,175,160,140,130,120,105,100$ \\
\hline & & 'C' & WCR (2) & $850,700,680,350,345,280,260,220,205,195,185,175,160,140,130,120,105,100$ \\
\hline & Asel & & WCR/MCR & $\begin{array}{l}800,750,650,600,400,385,365,350,310,300,285,240,239,220,200,195,190,185 \\
\quad 180,170,160,150,120,100,95,90,80,70,60,50,40\end{array}$ \\
\hline & Dral & & WCR/MCR & $\begin{array}{l}1900,750,550,507,450,360,350,340,300,290,280,270,240,235,215,200,190,185 \\
\quad+8 \text { bands }<120\end{array}$ \\
\hline $16 \mathrm{~S} 2-\mathrm{C} 2 \mathrm{R}$ & Xbal & & $\begin{array}{l}\text { WCR (37) } \\
\operatorname{MCR}(6)\end{array}$ & $6300,1850,600,495$ \\
\hline C1-C2 & Msel & & $\begin{array}{l}\text { WCR (8) } \\
\operatorname{MCR}(6)\end{array}$ & $200,165,155,110,95,87,65,50,42$ \\
\hline
\end{tabular}

${ }^{a}$ WCR ITS1, 45 individuals, MCR ITS1 6 individuals; WCR 12S-N4, 71 individuals; WCR CB2H-C1, 72 individuals; MCR 46 individuals; () indicates the number of individuals with polymorphic pattern.

*Bands that were not visible on all gels. 

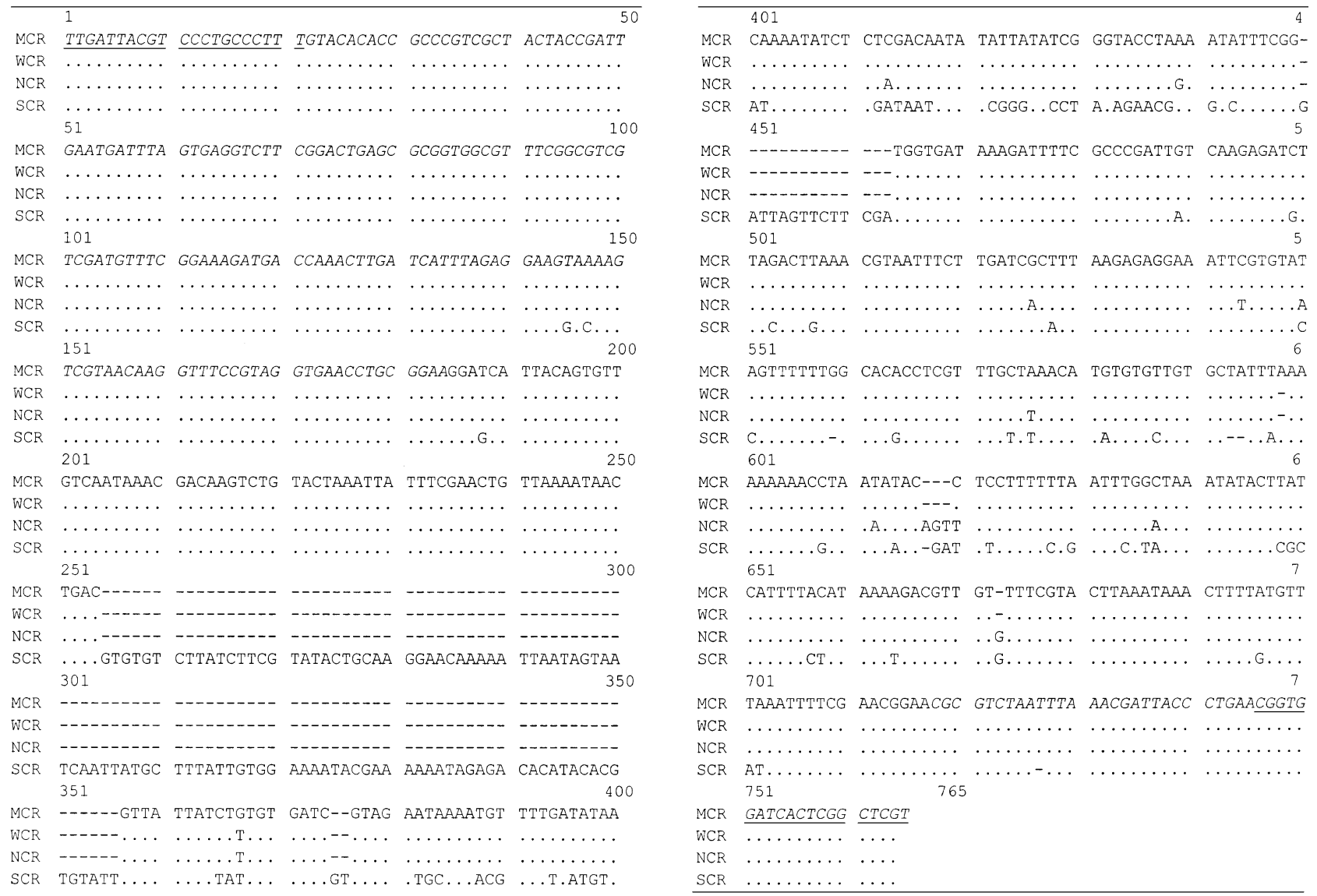

Figure 2. Sequence comparison for $D$. vs. vigifera (WCR), $D$. vs. zeae (MCR), $D$. barberi (NCR), and $D$. undecimpunctata howardi (SCR). '. indicate that the same nucleotide is present as that in MCR; -, indicates a deletion. Primer sequences are underlined and encoding regions (18S and 5.8) are italicized. GENBANK accession numbers are (MCR), (WCR), (NCR), and U90334 (SCR).

'B') in $34 \%(24 / 71)$ of the individuals. Both patterns were observed in each of the twelve collections examined (Table 3) and therefore are not useful for recognizing geographical nor insecticide resistance populations. All MCR had Dpnll pattern ' $A$ '. Four other rare polymorphisms were observed. 12S-N4 Alul 'B' was found in three individuals from the Brookings colony; 12S-N4 Alul 'C' was found in a Clay Center individual; $\mathrm{CB} 2 \mathrm{H}-\mathrm{C} 1 \mathrm{Sspl}$ 'B' was found in one Gresham individual; and CB2H-C1 Sspl ' $\mathrm{C}$ ' was found at Gresham and Clay Center (Table 2). RFLP analysis of mtDNA could not differentiate MCR from WCR (Fig. 3).

\section{Discussion}

The low level of genetic differentiation observed within and among WCR and MCR populations is supported by one allozyme study. A phylogenetic study of five Diabrotica species (Krysan et al., 1989) found minimal genetic differentiation among fifteen WCR and six MCR populations. Among other diabroticite beetles, low levels of allozyme
Table 3. Distribution of mtDNA 12S-N4 Dpnll restriction fragment patterns 'A' and 'B'.

\begin{tabular}{llll}
\hline Population & $\mathrm{R} / \mathrm{S}^{\mathrm{a}}$ & 'A' individuals & 'B' individuals \\
\hline WCR & & & \\
CC & $\mathrm{S}$ & 4 & 1 \\
$\mathrm{~N}$ & $\mathrm{R}$ & 3 & 1 \\
WZ & $\mathrm{R}$ & 4 & 2 \\
V & $\mathrm{R}$ & 3 & 3 \\
M & $\mathrm{S}$ & 2 & 2 \\
G & $\mathrm{R}$ & 4 & 2 \\
WC (NE) & $\mathrm{S}$ & 5 & 1 \\
D & $\mathrm{R}$ & 3 & 1 \\
C1432 & $\mathrm{S}$ & 1 & 3 \\
BR & $\mathrm{S}$ & 4 & 5 \\
WH & $\mathrm{S}$ & 4 & 2 \\
LF & $\mathrm{S}$ & 10 & 1 \\
total WCR & & $47(66 \%)$ & $24(34 \%)$ \\
MCR & & & \\
T & $\mathrm{S}$ & 20 & 0 \\
UV & $\mathrm{S}$ & 26 & 0 \\
Total MCR & & $46(100 \%)$ & \\
\hline
\end{tabular}

${ }^{\mathrm{a}}$ Resistant (R) or Sensitive (S) to methyl parathion and carbaryl. 
(a) Dpn II



(d) Alu I

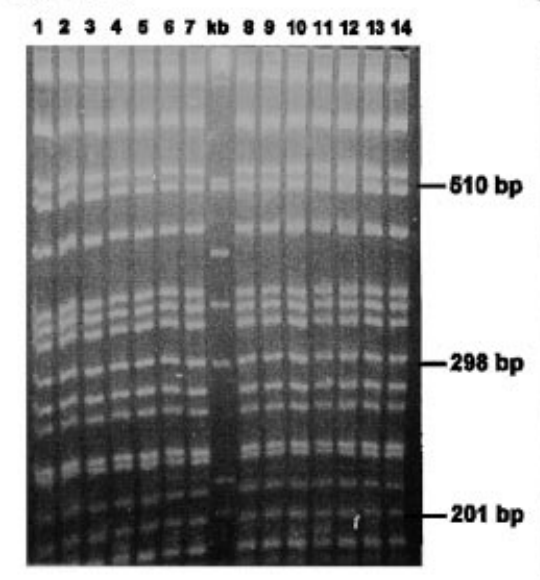

\section{(c) Dra I}

(b)

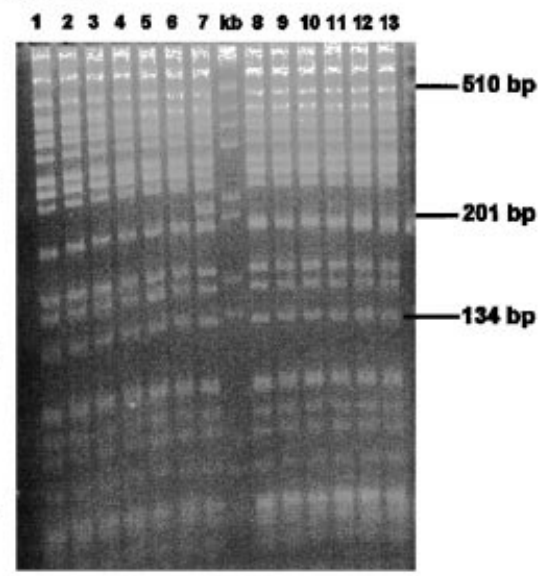

Figure 3. PCR-RFLP of corn rootworm mtDNA. (a) Dpnll fragments from WCR 12S-N4 amplicon showing ' $A$ ' and ' $B$ ' restriction patterns. Arrow denotes extra fragment in 'B' pattern. Lane 1, C1432; lanes 2-3, N; lanes 4-5; D; lane 6, kb ladder; lane 7, UV; lanes 8-10, BR. (b) 12S-N4 amplicon from WCR, NCR and SCR. Lanes 1-3, Dpnll; lanes 4-6, Hinfl; lane 7, kb ladder DNA marker; lanes 8-10, Swal. (c) Dral fragments from WCR CB2-C1 amplicon. Lanes 1-2, C1432; lanes 3-4, N; lanes 5-6, D; lanes 7-8, M; lanes 9-11, BR; lanes 12-14 WZ. (d) Alul fragments from WCR CB2-C1 amplicon. Lane 1, WZ; lanes 2-5, G; lanes 6-8, CC; lanes 9-10, V; lanes 11-12, WC; lane 13, WH. $1 \mathrm{~kb}$ ladder used as DNA size marker on all gels. Band size labels refer to the corresponding band in the marker lane. variation have also been observed in NCR. McDonald et al. (1985) did not detect any significant genetic differentiation among thirty-three geographically isolated populations of NCR. In a similar study, Krafsur et al. (1993) analysed twenty-one polymorphic loci from fourteen populations of NCR and showed high levels of gene flow among populations. Krafsur (1995) examined univoltine and semivoltine NCR populations and concluded that gene flow was virtually unrestricted between the phenotypes. However, significant ITS1 and mtDNA variation has been observed in NCR, and appears to be substantially greater than that within WCR (A. Szalanski and R. Roehrdanz, unpublished data).

Because only three WCR and two MCR were sequenced, we remain very cautious about claiming that the two site polymorphisms are diagnostic. Low levels of genetic diversity in the ITS1 and mtDNA regions among widely dispersed populations have been reported for other insect species including European corn borer, Ostrinia nubilalis (Marcon et al., 1999), stable fly, Stomoxys calcitrans (Szalanski et al., 1996), tobacco budworm,
Heliothis virescens (Roehrdanz et al., 1994), monarch butterfly, Danaus plexippus (Brower \& Boyce, 1991), gypsy moth, Lymanatria dispar (Bogdanowicz et al., 1993) and alfalfa weevil, Hypera postica (Erney et al., 1996). These species have high mobility or recent expansion from a genetic bottleneck in common. Gene flow is enhanced by high mobility as in tobacco budworm and monarch. Recent expansion is favoured by introduction into new habitats as for European corn borer, gypsy moth and alfalfa weevil. These factors may be contributing to the lack of genetic variation among WCR populations as well.

The absence of mtDNA variation between the WCR and MCR subspecies indicates a recent common evolutionary history. The boundary between the two phenotypes has remained discrete and stationary, even as WCR expanded eastward. Presumptive hybrid beetles have been collected infrequently along a narrow boundary between the two populations in the panhandle of Texas and central Mexico (Krysan et al., 1980; Giordano et al., 1997). Laboratory crosses between WCR and MCR displayed reduced egg hatch when WCR was the paternal parent 
(Krysan \& Branson, 1977). Electron microscopy revealed rickettsia-like bacteria, later classified as Wolbachia, in the reproductive tract of male WCR but absent in MCR (Degrugillier et al., 1991; Giordano et al., 1997). These Wolbachia appear to be responsible for the observed cytoplasmic incompatibility and may be a primary factor in maintaining the boundary between WCR and MCR. WCR cured of Wolbachia with tetracycline are fertile when crossed with MCR (Giordano et al., 1997). Because ITS1 and mtDNA PCR-RFLPs cannot differentiate between WCR and MCR, analysis of intermediates will not resolve the origin.

The paucity of genetic polymorphism in the ribosomal spacer and mitochondrial DNA diminishes the prospect of using these tools to quickly find molecular markers to track insecticide resistance, expansion of host range to include sorghum, increased tendency to deposit eggs outside of corn fields, or other behavioural modifications. Techniques detecting higher levels of polymorphism such as RAPD-PCR or AFLP may reveal markers more suitable for population level analyses of altered behaviours and insecticide resistance in WCR. Assays for genes or gene products directly involved may also prove useful, especially for resistance management.

\section{Experimental procedures}

\section{Rootworm samples}

WCR and MCR adults were obtained from the field locations listed in Table 1. In most cases, eggs were obtained from fieldcollected adults and reared to adulthood at the Northern Grain Insects Research Laboratory, Brookings, SD. $\mathrm{F}_{1}$ adults were frozen and stored at $-80^{\circ} \mathrm{C}$. Field collected beetles from Lancaster County, NE and Uvalde, TX, were preserved in $70 \%$ ethanol. Populations WZ, N and V from Phelps County, Nebraska, and populations $D$ and $G$ from York County, Nebraska, have been identified as resistant to methyl parathion and carbaryl. Other Nebraska populations are susceptible to those insecticides, and resistance has not been reported outside of Nebraska Meinke et al. (1998). Adult rootworms were preserved by immersion in $70 \%$ alcohol or freezing at $-80^{\circ} \mathrm{C}$. Frozen voucher specimens are being maintained at the ARS-USDA Biosciences Research Laboratory, Fargo, ND.

\section{DNA extraction, amplification and sequencing}

DNA for ITS1 sequencing was extracted from individual thoraces using a phenol/chloroform technique similar to Taylor et al. (1996). The primers rDNA2 (5'-TTGATTACGTCCCTGCCCTTT-3', Vrain et al., 1992) and rDNA1.58s (3'-GCCACCTAGTGAGCCGAGCA-5', Cherry et al., 1997) amplified a $3^{\prime}$ portion of the $18 S$ gene, the entire ITS1 region and a $5^{\prime}$ portion of the $5.8 S$ gene. Primers were synthesized by the University of Nebraska-Lincoln primer synthesis lab (Lincoln, NE). ITS1 PCR using $1.0 \mu \mathrm{L}$ of template DNA was done as described by Szalanski et al. (1997). Amplified DNA for sequencing was purified using Geneclean II (Bio 101, Inc. Vista, CA) and sequenced in both directions using a Prism DNA sequencer (Applied Biosystems, Inc.) located at the lowa State
University DNA sequence and synthesis facility (Ames, IA). Consensus sequences were derived from individual sequences in each direction using GAP (Genetics Computer Group, Madison, WI).

DNA for use in long PCR was extracted from individual insects using the high salt procedure of Cheung et al. (1993). Long PCR reactions were done as described by Roehrdanz (1995). Primers included C1 (C1-J-2195), C2 (C2-N-3662), N4 (N4-J-8944), 16SR (LR-J-12883), 16S2 (LR-N-12945), $12 \mathrm{~S}$ (SR-N-14588), CB2H (CB-N-10920) (Simon et al., 1994; Roehrdanz \& Degrugillier, 1998). MtDNA primers were synthesized by NBI, Plymouth, MN.

\section{Restriction fragment length polymorphism analysis}

Web Cutter 2.0 (Heiman, 1997) was used to predict restriction sites in ITS1 sequence data. ITS1 amplicons were digested according to manufacturer's recommendations (New England Biolabs, Beverly, MA) using the enzymes Apol, Ddel, Dral, Rsal and Taql (Cherry et al., 1997). Restriction enzymes Alul, Asel, Dral, Sspl, Hinfl, Swal, Xbal, Haelll, ScrF I, and Dpnll were used for the mtDNA amplicons. Msel was also used to digest some of the smaller mtDNA amplicons. Digest products were visualized by separation with seakem or metaphor agarose (FMC) or polyacrylamide gel electrophoresis and stained with ethidium bromide (Taylor et al., 1997). The number of base pairs surveyed with each mtDNA amplicon was estimated using the formula (number of restriction fragments -1 ) $\times$ (length of the recognition sequence for each restriction enzyme). Because there is a 2-kb overlap in the large PCR amplicons the total number of base pairs was corrected for restriction sites counted twice by subtracting the number of bases equal to the ratio of the overlap to the total amplicon length $(2 \mathrm{~kb} / 8.7 \mathrm{~kb})$ for one of the amplicons.

\section{Acknowledgements}

We thank R. Nix, T. Harris and P. Senechal for technical assistance and D. Hovland and C. Nielson for maintaining the MCR and WCR colonies. B. D. Siegfried and L. J. Meinke collected the Nebraska WCR samples. C. Hoffman helped with the MCR samples from Uvalde, TX. K. P. Pruess, R. D. Peterson II, and B. D. Siegfried provided helpful suggestions and critical reviews of the manuscript. This is Journal Paper no. 12458 of the Nebraska Agricultural Research Division.

\section{References}

Ball, H.J. and Weekman, G.T. (1963) Differential resistance of corn rootworms in Nebraska and adjoining States. $J$ Econ Entomol 56: 553-557.

Bogdanowicz, S.M., Walner, W.E., Bell, J., Odell, T.M. and Harrison, R.G. (1993) Asian gypsy moths (Lepidoptera: Lymantriidae) in North America: evidence from molecular data. Ann Entomol Soc Am 86: 710-715.

Brower, A.V.Z. and Boyce, T.M. (1991) Mitochondrial DNA variation in monarch butterflies. Evolution 45: 1281-1286.

Cherry, T., Szalanski, A.L., Todd, T.C. and Powers, T.O. (1997) The internal transcribed spacer region of Belonolaimus (Nemata: Belonolaimidae). J Nematol 29: 23-29.

Cheung, W.Y., Hubert, N. and Landry, B. (1993) A simple and 
rapid DNA microextraction method for plant, animal, and insect suitable for RAPD and other PCR analysis. PCR Meth App/ 3: 69-70.

Degrugillier, M.E., Degrugillier, S.S. and Jackson, J.J. (1991) Nonoccluded, cytoplasmic virus particles and rickettsia-like organisms in testes and spermathecae of Diabrotica virgifera. $J$ Invertebr Pathol 57: 50-58.

Erney, S.J., Pruess, K.P., Danielson, S.D. and Powers, T.O. (1996) Molecular differentiation of alfalfa weevil strains (Coleoptera: Curculionidae). Ann Entomol Soc Am 89: 804-811.

Fuller, B.W., Boetel, M.A., Walgenbach, D.D., Grundler, J.A., Hein, G.L., Jarvi, K.J., Keaster, A.J., Landis, D.A., Meinke, L.J., Oleson, J.D., Ostlie, K.R., Tollefson, J.J., Wedberg, J.L., Wilde, G.E. and Evenson, P.D. (1997) Optimization of soil insecticide rates for managing corn rootworm (Coleoptera: Chrysomelidae) larvae in the north central United States. $J$ Econ Entomol 90: 1332-1340.

Giordano, R., Jackson, J.J. and Robertson, H.M. (1997) The role of Wolbachia in reproductive incompatibilities and hybrid zones of Diabrotica beetles and Gryllus crickets. Proc Natl Acad Sci USA 94: 11439-11444.

Heiman, M. (1997) Webcutter 2.0. <http://first-market.com/ firstmarket/cutter/cut2.html>.

Krafsur, E.S. (1995) Gene flow between univoltine and semivoltine northern corn rootworm (Coleoptera: Chrysomelidae) populations. Ann Entomol Soc Am 88: 699-704.

Krafsur, E.S., Nariboli, P. and Tollefson, J.J. (1993) Gene diversity in natural Diabrotica barberi Smith and Lawrence populations (Coleoptera: Chrysomelidae). Ann Entomol Soc Am 86: 490-496.

Krysan, J.L. (1986) Introduction: biology, distribution, and identification of pest Diabrotica. Methods for the study of pest. Diabrotica (Krysan, J.L. and Miller, T.A., eds), pp. 1-23. Springer-Verlag, New York.

Krysan, J.L., McDonald, I.C. and Tumlinson, J.H. (1989) Phenogram based on allozymes and its relationship to classical biosystematics and pheromone structure among eleven diabroticites (Coleoptera: Chrysomelidae). Ann Entomol Soc Am 82: 574-581.

Krysan, J.L. and Smith, R.F. (1987) Systematics of the virgifera species group of Diabrotica (Coleoptera: Chrysomelidae: Galerucinae). Entomography 5: 375-484.

Krysan, J.L., Smith, R.F., Branson, T.F. and Guss, P.L. (1980) A new subspecies of Diabrotica virgifera (Coleoptera: Chrysomelidae): description, distribution and sexual compatibility. Ann Entomol Soc Am 76: 197-202.

Krysan, J.L. and Branson, T.F. (1977) Inheritance of diapause intersity in western corn rootworm, Diabrotica virgifera. J Hered 68: 415-417.

Levine, E. and Oloumi-Sadeghi, H. (1991) Management of diabroticite rootworms in corn. Ann Rev Entomol 36: 229-255.

Marcon, P.C.R.G., Taylor, D.B., Mason, C.E., Hellmich, R.L. and
Siegfried, B.D. (1999) Genetic similarity among phermone and voltinism races of Ostrinia nubilis (Hubner) (Lepidoptera: Pyralidae). Insect Mol Biol 8: 213-222.

McDonald, I.C., Krysan, J.L. and Johnson, O.A. (1985) Genetic variation within and among geographical populations of Diabrotica barberi (Coleoptera: Chrysomelidae). Ann Entomol Soc Am 78: 271-278.

Meinke, L.J., Siegfried, B.D., Wright, R.J. and Chandler, L.D. (1998) Adult susceptibility of Nebraska western corn rootworm (Coleoptera: Chrysomelidae) populations to selected insecticides. $J$ Econ Entomol 91: 594-600.

Metcalf, R.L. (1983) Impacts and prognosis of resistance to insecticides. Pest Resistance to Pesticides (Georghiou, G.P. and Saito, T., eds), pp. 703-733. Plenum Press, New York.

Roehrdanz, R.L. (1995) Amplification of complete insect mitochondrial genome in two easy pieces. Insect Mol Biol 4: 169-172.

Roehrdanz, R.L. and M.E. Degrugillier (1998) Long sections of mitochondrial DNA amplified from 14 orders of insects using conserved PCR primers. Ann Entomol Soc Am 91: 771-778.

Roehrdanz, R.L., Lopez, J.D., Loera, J. and Hendricks, D.E. (1994) Limited mitochondrial DNA polymorphism in North American populations of Heliothis virescens (Lepidoptera: Noctuidae). Ann Entomol Soc Am 87: 856-866.

Simon, C., Frati, F., Beckenbach, A., Crespi, B., Liu, H. and Flook, P. (1994) Evolution, weighting, and phylogenetic utility of mitochondrial gene sequences and a compilation of conserved polymerase chain reaction primers. Ann Entomol Soc Am 87: 651-701.

Stewart, J.W., Cocke, J. Jr, Taylor, J. and Williams, R. (1995) Mexican corn rootworm emergence from corn fields where sorghum was grown the previous season. Southwestern Entomol 20: 229-230.

Szalanski, A.L., D.D. Sui, T.S., Harris and T.O. Powers (1997) Identification of cyst nematodes of agronomic and regulatory concern by PCR-RFLP of ITS1. J Nematol 29: 255-267.

Szalanski, A.L., Taylor, D.B. and Peterson, R.D.I.I. (1996) Population genetics of stable fly (Diptera: Muscidae) in Nebraska. $J$ Med Entomol 33: 413-420.

Taylor, D.B., Peterson, R.D.I.I., Szalanski, A.L. and Petersen, J.J. (1997) Mitochondrial DNA variation among Muscidifurax spp. (Hymenoptera: Pteromalidae), pupal parasitoids of filth flies (Diptera). Ann Entomol Soc Am 90: 814-824.

Taylor, D.B., Szalanski, A.L., Peterson, R.D. and I.I. (1996) Identification of screwworm species (Diptera: Calliphoridae) by polymerase chain reaction-restriction fragment length polymorphism. Med Vet Entomol 10: 63-70.

Vrain, T.C., Wakarchuk, D.C., Levesque, A.C. and Hamilton, R.I. (1992) Intraspecific rDNA restriction fragment length polymorphism in the Xiphinema americanum group. Fundam Appl Nematol 15: 563-573. 